\title{
Hvad så vi?
}

\section{Fotografiet og 9/11}

Vi ved alle sammen, hvad der skete i New York om morgenen d. 11. september 2001, eftermiddag dansk tid. To fly fløj ind i World Trade Center, hvis to tårne brød i brand og styrtede sammen, så næsten 3000 mennesker mistede livet.

De færreste af os var rent faktisk til stede i New York den morgen. Vi så og hørte om det gennem medierne. Men hvad så vi 11. september og i dagene umiddelbart efter? Og var det, vi så, en medialiseret og dermed uvirkelig og fordrejet, måske ligefrem propagandistisk fremstilling af, hvad der virkelig skete? Der er i al fald en generel billedskepsis, som mange kulturkritikere har udtrykt, og som denne artikel forsøger at gøre op med eller i al fald nuancere.

Hvad husker vi nu mere end syv år efter? Vi husker måske fotografiet af manden, der har kastet sig ud fra World Trade Center og er fotograferet i frit fald med hovedet nedad, folk der løber desperat af sted foran en kæmpe grå skrækfilmslignende sky, kvinden der grædende holder et fotografi af sin tabte elskede frem, ruinerne i den opstående sol d. 12. september eller de tre brandmænd, der hejser det amerikanske flag i ruinerne. Chokket har lagt sig nu. Berøres vi ikke længere af fotografierne? Bringer gensynet med dem i dag os tættere på eller fjernere fra selve begivenheden? Hvis vi ser de fotografier, syv år efter, er det så fotografiernes mytologi og ikonicitet, vi ser, eller er det den virkelige begivenhed? Eksisterer begivenheden i New York d. 11. september kun, fordi angrebet og dets følgevirkninger blev fotograferet og filmet? Og har fotografierne skærpet vores forståelse af, hvad der skete - eller snarere svækket den? Denne artikel vil fra et helikopterperspektiv i år 2008 fors $\varnothing$ ge at give et diskuterende overblik over fotografiets mangefacetterede brug i dagene umiddelbart efter 11. september 2001.

\section{Den mest fotograferede begivenhed}

Mange af os kan sikkert huske præcis, hvor vi var, da vi fik at vide, at World Trade Center havde været udsat for et flyangreb af en slags kl. 14.46 dansk tid. Allerede ét 

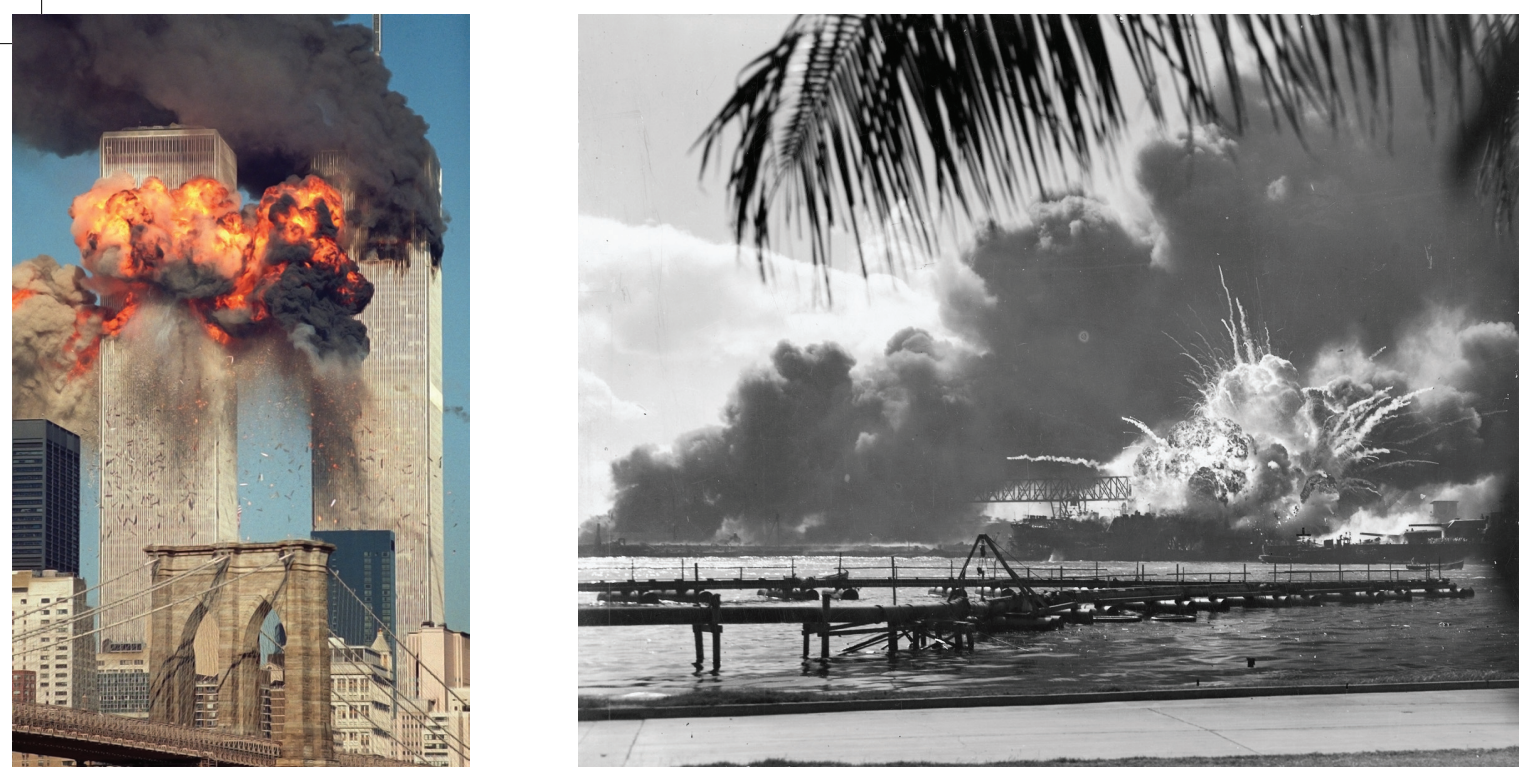

minut efter, at det første fly havde ramt det ene tårn, havde CNN et kamera på toppen af en skyskraber, hvorfra de sendte live resten af dagen. Der gik 18 minutter, før det næste fly ramte det andet tårn, så de fleste havde tid til at komme i nærheden af et tv og kunne derfor se det ske i form af levende billeder. Disse sekvenser, især den privatoptagelse, hvor man ser tårnene styrte sammen og hører en mand råbe 'Holy shit' på lydsporet, bragte begivenheden direkte ind i de danske stuer, ja hele jorden rundt.

Men i dag husker vi måske allermest fotografierne, som standsede kaos og lod os betragte det i stivnede småbidder. Det er fotografierne, der er gået over i historien som ikoner for noget særligt, noget bemærkelsesværdigt, et pludseligt indbrud af det ubegribelige. I dagene efter var det netop ord som 'ubegribeligt' og 'uforståeligt', der gik igen blandt både journalister og indkaldte eksperter, ligesom det i øvrigt også gjaldt for sprogbruget i kølvandet på 2. Verdenskrigs afslutning og afsløringen af de mange udryddelseslejre og massegrave i Tyskland - uden sammenligning i øvrigt. Der skulle billeder til, før folk begyndte at forstå. 9/11 var ikke fattig på billeder, tværtimod, vi havde dem som sagt i stuen stort set samtidig med, at begivenhederne fandt sted. Og alle spisesedler og avisforsider verden over var fyldt med fotografier af begivenheden samme dag og i mange dage derefter.

Den franske fotohistoriker Clément Chéroux har for nylig lavet en systematisk undersøgelse af 400 amerikanske aviser, der udkom d. 11. og d. 12. september (Chéroux 2007). Angrebet på World Trade Center er fotojournalistikkens mest fotograferede begivenhed nogensinde, men samtidig var der en meget lille variation i de anvendte fotografiers motiver. $95 \%$ af de undersøgte aviser reproducerede seks nogenlunde ens, genkommende motiver. Hovedmotivet, både i amerikansk og i europæisk presse, var de to skyskrabere med ild i midten og en stor, sort røgsky henover. Chéroux fremhæver, at ensartetheden også skyldes, at de små billedbureauer er forsvundet siden begyndelsen af 1990'erne til fordel for store verdensomspændende bureauer som Reuters, France-Presse og Associated Press, der i dag distribuerer de samme fotos over hele kloden. $72 \%$ af de fotografier, Chéroux har undersøgt, stammer fra Associated Press, hvilket i den grad demonstrerer globali- 
seringens effekt på medierepræsentationen. Ud over at mange altså så de samme, få fotografier, så har mange også nævnt fornemmelsen af déjà-vu, af at have set dem før. Chéroux spørger derfor i artiklen: "hvad er det, disse billeder gentager?" (Chéroux 2007: 151).

Da jeg blev inviteret til at skrive denne artikel til Passage, rullede der straks en imaginær stillbilledfilm frem for mit indre øje med de fotografier, jeg kunne tænke mig at inkludere i artiklen: Den brændende skyline, brandmændene der rejser flaget, den døde præst, ruinerne dagen efter. For sjov skyld gennemførte jeg en aldeles uvidenskabelig, empirisk undersøgelse på det hold af 25 andetårsstuderende på litteraturvidenskab, jeg har i efteråret 2008. Jeg bad dem svare på spørgsmålet "Hvad så du 11. september?" og angive max. tre motiver. Jeg havde forventet ganske få og ensartede motiver oplistet, men det viste sig, at min optællingsliste rummede lige så mange motiver, som der var studerende. Et motiv var dog den helt klare topscorer, nemlig det samme som iflg. Chéroux var mest udbredt i de amerikanske medier: de brændende skyskrabere omsluttet af sort røg netop som fly nummer to har ramt. "Det lignede en dårlig amerikansk katastrofefilm fra 70’erne", som én tilføjer til sin besvarelse. På andenpladsen kom - til min overraskelse - den faldende mand, hvilket muligvis kan skyldes, at det er litteraturstuderende, og fotografiet er blevet 'udødeliggjort' af forfatterne Jonathan Safran Foer (Extremely Loud \& Incredibly Close, 2005) og Don DeLillo (Falling Man, 2007) (se andetsteds i dette nummer), som en af de adspurgte faktisk selv nævner i en kommentar, eller i Henry Singers britiske dokumentarfilm 9/11. The Falling Man. Ingen nævnte de tre brandmænd og den døde præst, mens jeg er ret sikker på, at netop de to fotografier ville have været med på en tilsvarende amerikansk liste.

Rammer, matricer, formler, formateringer...

Chéroux' overordnede analytiske pointe er den pessimistiske og mediekritiske, at det er populærkulturen, især Hollywoodindustrien, der tilbyder et indskrænket og snævert fortolkningsfællesskab i forhold til en begivenhed som 9/11. Men jeg vil hævde, at fortolkningsfællesskabet er langt bredere og mere facetteret, og at det ikke nødvendigvis er negativt, at vi har brug for at kunne fortolke billeder i lyset af det allerede velkendte for overhovedet at kunne se og forstå dem.

I indledningen til antologien Mediernes 11. september definerer redaktøren Lars Qvortrup offentligheden som et "fortolkningslaboratorium", hvor der hurtigt blev skabt en vifte af forskellige velkendte fortolkningsrammer for at forstå det ufattelige: "Resultatet var ikke konsensus, dvs. en fælles offentlig fortolkning af begivenhederne. Resultatet var derimod en struktureret dissensus" (Qvortrup (red.) 2002: 8). I samme antologi anvender medieforskeren Kirsten Drotner begrebet "matricer" for at betegne de velkendte fortolkningsrammer, som medierne greb til for at skildre begivenheden. Hun beskriver eksempelvis, hvordan mange mundtlige kommentatorer anvendte fiktionen og filmen som ramme og talte om, at det lignede en Hollywoodfilm, "ikke, fordi de troede, terrorangrebene var fiktion, men fordi fiktionen var den oplagte forståelsesramme, der gav mening i situationen" (Drotner 2002: 36). Hun skriver endvidere: 
4 Det var dagen, der demonstrerede, at mennesker er meningsskabende væsener, der søger at forstå nye oplevelser i lyset af de gamle ved at pendle mellem det ukendte og det velkendte, gentagelser og afbrydelser. Medierne er centrale forståelses- og fortolkningsredskaber i vores møder med det andet og de andre. Disse møder sætter tilvante selvfølgeligheder i relief, idet vi søger at begribe det anderledes og fremmede ud fra det velkendte og vante. (Drotner 2002: 39)

Den franske historiker Pierre Nora - som vi kender for hans teori om "erindringssteder" - anvender også betegnelsen matrice i forhold til individets mulighed for at skabe historisk erindring. ${ }^{\mathrm{I}}$ Den amerikanske kunsthistoriker Stephen Eisenman bruger Aby Warburgs begreb "patosformler" som det gennemgående begreb i bogen The Abu Ghraib Effect, hvor han analyserer Abu Ghraib-fotografierne og deres videre skæbne i de vestlige medier. Her viser han, hvordan de klassiske græske statuers skildring af lidelse ligger som en sådan ubevidst, men meget udbredt vestlig "patosformel", der på én gang prægede soldaternes torturfotografier fra Abu Ghraib og den senere aflæsning af dem. Det er i det hele taget en velkendt psykologisk mekanisme, at man forstår noget bedre, hvis man kan relatere det til noget, man kender til i forvejen. Det er naturligvis en mekanisme, som også kan bruges i propagandaøjemed, hvilket der fx er mange eksempler på fra Stalintidens kalkulerede anvendelse af fotografiet.

Clément Chéroux bruger begrebet "inter-ikonicitet", som han udvikler i forhold til begrebet "intertekstualitet", dvs. tekster, der indirekte citerer, står på skuldrene af eller refererer til andre tekster. Er disse matricer, denne inter-ikonicitet, som jeg vil vise eksempler på i det følgende, så godt eller skidt? Det kan være begge dele og er altså ikke nødvendigvis negativt, vil jeg hævde. Lars Qvortrup tager, som jeg også gør det i denne artikel, afstand fra en "vulgær-konstruktivistisk påstand om at medierne 'konstruerer' verden. Nej, de formaterer verden, de gør fænomener tilgængelige ved at indsætte dem i én eller flere fortolkningsskabeloner [...] i en ikke-intentionel proces" (Qvortrup 2002: 155). "Offentlighedens funktion er ikke at frembringe en fælles, diskursiv sandhed, men at frembringe et tematiseret rum af stridende fortolkninger, der i deres dynamiske kompleksitet kan matche den omverdenskompleksitet, som attentatet mod World Trade Center fremkaldte" (Qvortrup 2002: 148).2

Hvilke forskellige matricer, forståelsesrammer og fortolkningsskabeloner tilbød fotografiet os d. 11. september og i dagene efter? Og hvordan hænger æstetik og etik sammen i denne forbindelse?

\section{Sort røg}

Clément Chéroux analyserer især to genkommende motiver i en amerikansk kontekst: de brændende tårne omsluttet af tyk, sort røg og fotografiet af de tre brandmænd, taget af Thomas Franklin. Det første motiv - i lidt forskellige variationer - var det mest udbredte, både i USA og Europa, mens det sidste måske er det fotografi, der har fået det største ikoniske efterliv, især i en amerikansk sammenhæng. 

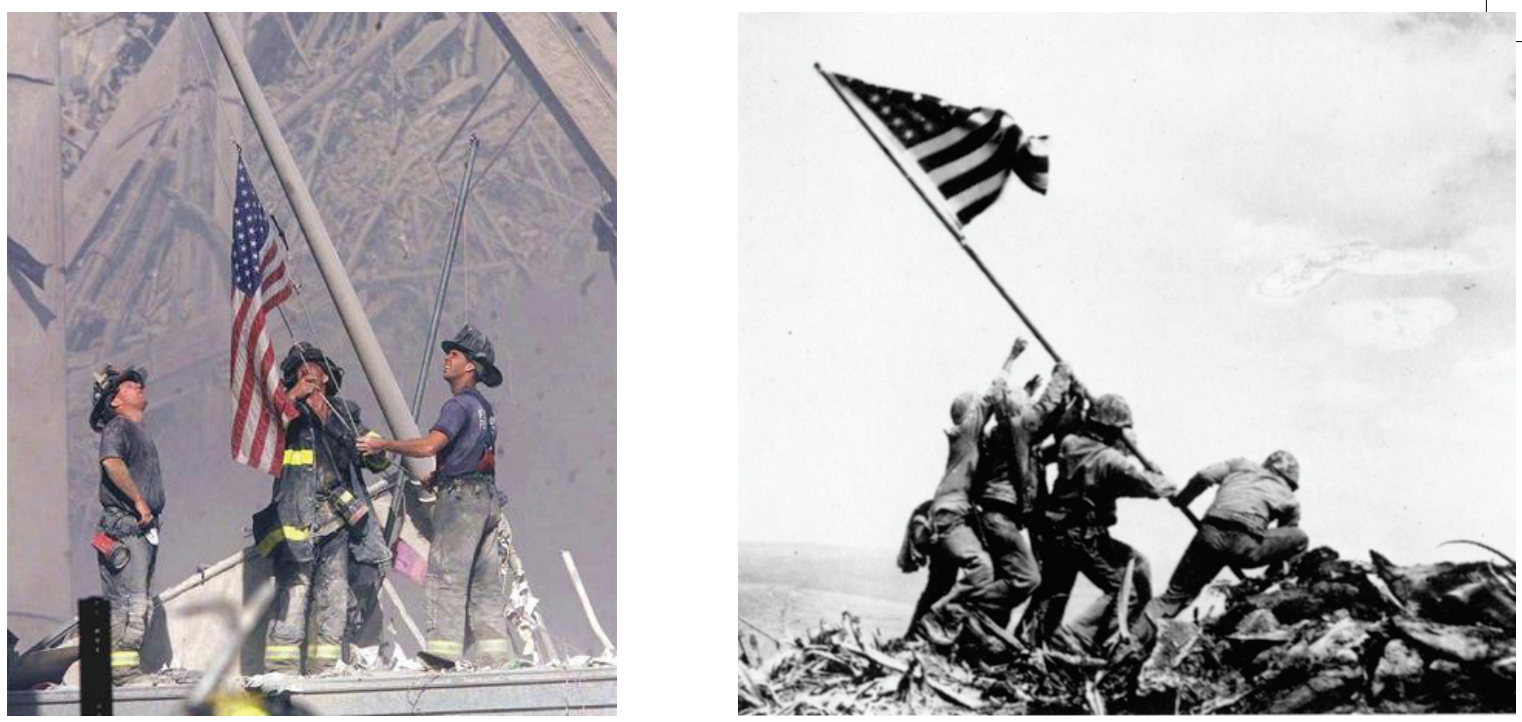

Chéroux påpeger, og har i en anden sammenhæng udfoldet, ${ }^{3}$ hvordan motivet med den sorte røg over tårnene og/eller skylinen ganske vist også blev brugt i de europæiske aviser, men når man ser det i sammenhæng med avisernes overskrifter, så blev motivet - ofte gengivet med nærmest sublim skønhed med fokus på ild og røg - i Europa knyttet til noget uforklarligt, et pludseligt katastrofisk indbrud, et uforklarligt chok, ikke ulig Kants berømte filosofiske skildring af 'det sublime'. I USA derimod blev det samme motiv forankret med tekstlige overskrifter som "It's War", "Assault on America", "Attacked" eller "Infamy". Det sidste refererer direkte til den betegnelse om japanernes angreb på Pearl Harbor i 1941, som præsident Roosevelt brugte i sin legendariske radiotale til det amerikanske folk efter angrebet. Chéroux påviser, hvordan sammenligningen med Pearl Harbor var den mest genkommende analogi brugt i de amerikanske medier. The News-Gazette havde ligefrem overskriften "Second Pearl Harbor" til det røgfyldte motiv, og flere aviser bragte et mindre fotografi af de brændende skibe i Pearl Harbor sammen med fotografiet af det brændende World Trade Center. På The Sun fyldte et Pearl Harbor-fotografi hele forsiden under overskriften "Never forget", mens New Yorks brændende skyline var indsat i en lille version øverst på siden.

Chéroux kæder denne analogi tæt sammen med det andet hovedfotografi, Thomas Franklins fotografi af de tre brandmænd, der om eftermiddagen hentede en skibsmast med et amerikansk flag fra et skib i den nærliggende flod og plantede det i de rygende ruiner. Franklin har i flere sammenhænge forklaret, hvordan brandmændenes handling sikkert var spontan og ret ubevidst, ligesom hans egen indskydelse til at fotografere motivet var det. Franklin var ansat på New Jersey-avisen The Record, men hans fotografi blev samme aften distribueret af Associated Press. Dette billede blev det mest og bredest reproducerede enkeltfotografi fra 9/11. Det udkom hurtigt på frimærke, og to år efter var frimærket solgt i 128 millioner eksemplarer, ligesom det er blevet trykt på t-shirts, krus, postkort og oversat til et skulpturelt mindesmærke. Franklins fotografi mimer Joe Rosenthals berømte fotografi fra den japanske $\varnothing$ Iwo Jima, hvor seks amerikanske marinesoldater rejser det amerikanske flag på toppen af øens bjerg Suribachi efter en vellykket invasion i 1945. Også dette 
fotografi er siden blevet et fotohistorisk ikon, der bl.a. er udkommet på frimærker og også har dannet forlægget for et berømt mindesmærke på militærkirkegården i Arlington, Washington DC. Og mens Franklins motiv opstod i en form for spontan og ubevidst mimen af Rosenthals fotografi, var Rosenthals fotografi faktisk en bevidst mimende geniscenesættelse af en spontan handling foretaget kort forinden, men bl.a. med et mindre flag.

De to fotografier fortolker altså 9/11 via en krigsmetaforik: USA er blevet angrebet ligesom i Pearl Harbor i 1941, men samtidig har man hurtigt formået at mobilisere sig heroisk mod fjenden, tage kampen op, og det skal nok lykkes amerikanerne at besejre fjenden, som man gjorde det på Iwo Jima i 1945. Chéroux' pointe er nu, at denne historiske fortolkningsramme om 9/11 i mindre grad beror på konkrete historiske forlæg fra 2. Verdenskrig, men i højere grad på en "inter-ikonisk" ramme, der handler om erindringen om historien, som den er blevet overleveret eller rettere kollektivt konstrueret via massemedierne. 2001 var nemlig 60-året for bombardementet af Pearl Harbor, og den Disneyproducerede blockbusterfilm Pearl Harbor havde haft premiere tidligere på året, nemlig på Memorial Day 30. maj. Filmen og ikke mindst dens vidt distribuerede plakat fokuserer næsten udelukkende på det visuelle røginferno, og det er altså denne visuelle fortolkning af den historiske erindring, som amerikanerne havde på nethinden, da de oplevede 9/11.

Året før, i 2000, havde forfatteren James Bradley, søn af en af de seks marinesoldater fra Iwo Jima, udgivet den journalistiske, populærhistoriske bog Flags of Our Fathers med Rosenthals fotografi på forsiden (den bog, der i øvrigt dannede forlæg for Clint Eastwoods senere film af samme navn). Bogen var straks røget ind på New York Times' bestsellerliste, hvor den holdt sig i 40 uger, helt frem til juli 2001, og kort tid efter blev erstattet af paperbackudgaven. Netop disse to motiver var altså på forhånd massivt til stede i den amerikanske visuelle kultur d. 11. september 2001: "Mediebillederne fra 11. september refererer således ikke til historien i sig selv, men til erindringen, en erindring filtreret gennem Hollywood og den spektakulære information/skuespilsberetningen [fr. "l'information spectacle"]" (Chéroux 2007: 163), siger Chéroux og kalder dem eksempler på global "infotainment", som peger på en uniformeret forståelse af virkeligheden, der ikke blot går rumligt på tværs af den globale verden, men også tidsligt tilbage i forhold til en alment standardiseret historiefortolkning. Man hører ekkoet fra Guy Debords "société du spectacle", som
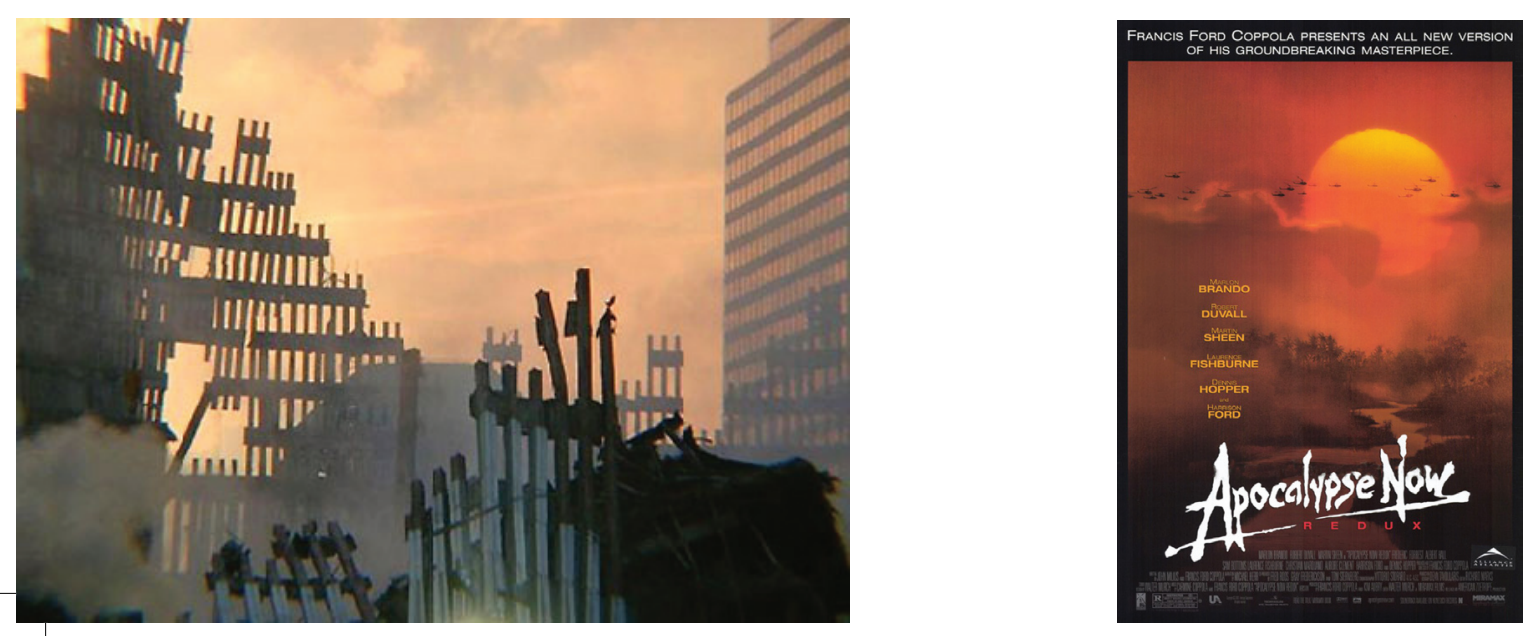

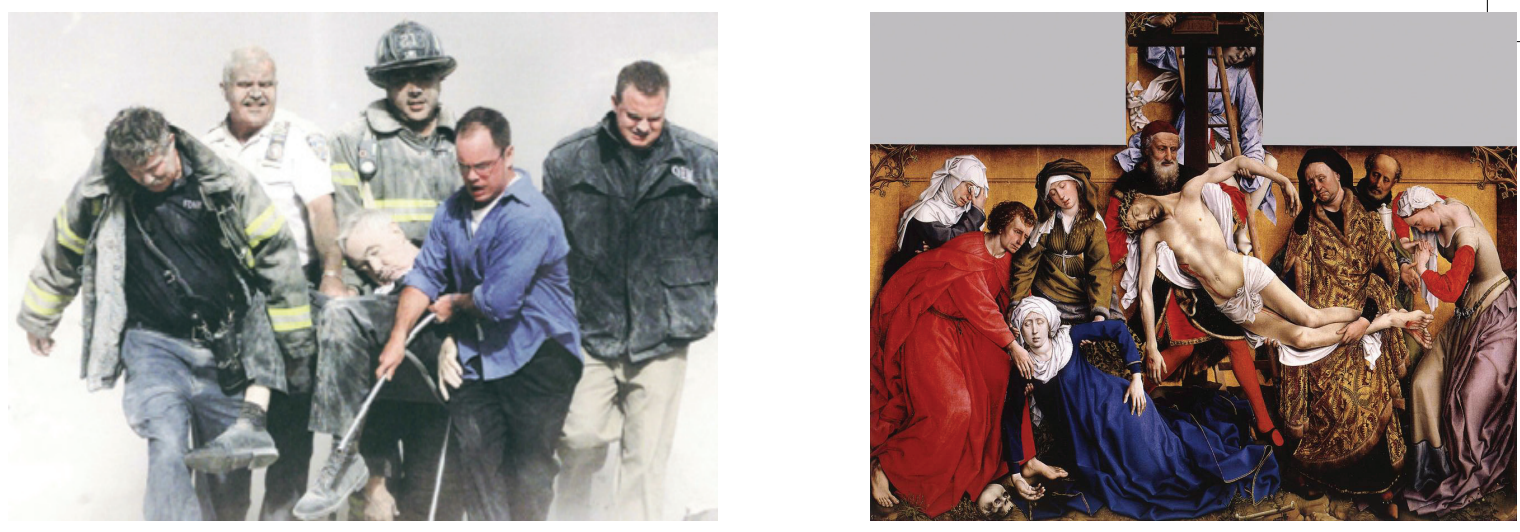

siden er blevet genoptaget af Jean Baudrillard, hvilket jeg vil vende tilbage til. Men først et par motiver mere.

\section{Apokalypsen og den rene katastrofes skønhed}

De billedlige forståelsesmatricer, som blev bragt i anvendelse i dagene efter 11 . september, forholdt sig ikke nødvendigvis kun til den umiddelbare fortids visuelle kultur. Også mere alment udbredte og måske mere dybtliggende 'patosformler' blev bragt i anvendelse. Som sagt brugte mange europæiske aviser samme røgfyldte motiv, men her repræsenterede det snarere en form for traumatisk, ren katastrofe eller apokalypse. Da støvet fra murbrokkerne havde lagt sig, og ilden var nogenlunde slukket, var mange aviser fra d. 13. og frem præget af denne apokalyptiske stemning: noget var ødelagt for altid, verden skulle fødes på ny, jf. betegnelsen "Ground Zero", som syntes at være spontant opstået. Fotografierne af ruinerne i røgtåger, flere af dem med en opstående sol som baggrund, står i en sådan apokalypses tegn. De minder om plakaten til Francis Ford Coppolas film Apocalypse Now, der skildrer den menneskelige død og depravation under Vietnamkrigen, og som under overskriften "This is the end" viser et smukt, tåget landskab med en stærk sol i baggrunden, hvorigennem der flyver en insektlignende hær af helikoptere. Disse smukke afslutnings-/verdens-begyndelse-fotografier minder om motiver, man mere eller mindre ubevidst genkender fra kunsthistorien fra fx tidlige skildringer af Babelstårnets ødelæggelse eller Albrecht Altdorfers kaotiske gengivelse af det berømte Alexanderschlacht fra 1529 til sådan noget som de tyske ekspressionisters malerier af krigshærgede landskaber efter 1 . Verdenskrig, fx Ludvig Meidners afsvedede skyttegravslandskab berørt af den lave morgensols første stråler, eller en maler som Anselm Kiefers ligeledes afbrændte tyske landskaber fra 1980'erne, der i en kompleks blanding af gru og skønhed skildrer 2. Verdenskrigs ødelæggelser.

Flere af de mest reproducerede fotografier taler således inter-ikonisk med andre fotografier, malerier og motiver, som de fleste betragtere ubevidst genkender gennem de nye fotografier. Som fotografiet af den døde Father Mychal Judge, der som brandmandskorpsets præst døde i bygningen, mens han forsøgte at velsigne de døde brandmænd. På fotografiet, taget af Shannon Stapleton og distribueret af Reuters, bæres han ud af fem mænd, halvt siddende i en let stålstol. Motivet minder om det klassiske 'Kristus nedtaget fra korset'. Også her er der fra både aktører og 


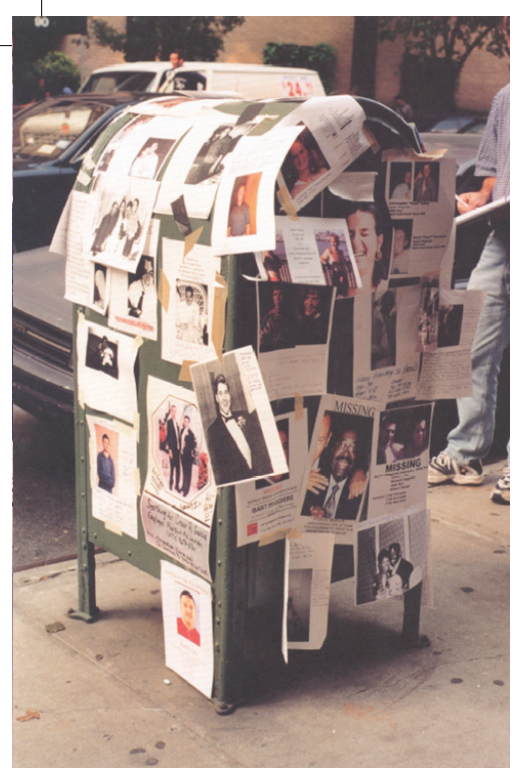

fotografs side utvivlsomt tale om en ubevist handling, men at billedet blev så vidt distribueret, vidner om, at det har ramt en alment genkendelig patosformel.

Flere af fotografierne af den brændende skyline, taget tæt på eller langt fra, fx fra Brooklyn Bridge, minder også om nogle af fotohistoriens mest kendte ikoniske New York-fotografier taget i metropolens store vækstår helt i begyndelsen af det 20. århundrede af legendariske fotografer som Alfred Stieglitz og Alvin LangdonCoburn. Disse fotografier står i dag som modernitetsoptimistiske hyldester til New York og er vidt distribueret på postkort og i foto- og byhistoriske oversigtsværker og kom som en ubevidst matrice til at danne den melankolske klangbund bag mange af fotografierne fra terrorangrebet.

\section{Ofrene, sorgarbejdet}

Endelig vil jeg nævne en helt anden type af fotografier, som florerede ikke blot i medierne i mange dage efter 11. september, men i højeste grad i selve det offentlige rum i New York, nemlig de efterladtes egne, forskellige former for portrætter og amatørfotografier af de savnede eller af byen i tiden efter angrebet.

Katastrofen fik et menneskeligt ansigt i kraft af forskellige genkommende motiver: folk der holder grædende om hinanden og trøster hinanden, folk der løber foran støvskyen, brandmænd i forskellige former for heroisk aktion eller simpel opgivelse. Men det mest påfaldende manglende motiv var de døde. Dels var de svære at finde, fordi de var begravet under mange etagers murbrokker, dels blev de ikke vist af etiske årsager. New York-avisen Daily News havde som en af de få aviser et fotografi af en afreven hånd (Sontag 2003: 68), men ellers anså de fleste aviser det for upassende, generelt og af hensyn til de efterladte, at vise fotos af døde og lemlæstede. Den døde Father Judge kom derfor til at symbolisere de døde per se ligesom det berømte fotografi af "the falling man", som også var det fotografi, der kom ind som nummer to på mine studerendes huskeliste. Det og lignende fotografier af folk, der kastede sig i døden fra den brændende bygning, blev dog kun vist få gange og rejste 
i sig selv en heftig etisk debat i de amerikanske medier.

Der, hvor man fik sat ansigt, krop og identitet på de mange døde, var i de spontant opståede billedtavler rundt i New Yorks byrum omkring World Trade Center; på mure, postkasser, butiksvinduer. De var skabt som efterlysningstavler, hvor almindelige mennesker, de efterladte, med tekst og foto efterlyste deres savnede venner og familiemedlemmer. Som dagene skred frem, kom de reelt til at fungere som en form for grædemure til både individuel og kollektiv sorgbearbejdelse. Flere blev suppleret med stearinlys eller personlige genstande som tøjbamser. Disse fotografier af glade mennesker, taget af deres familie, på deres prom night, på fødsels- eller bryllupsdagen, kom i den grad til at tydeliggøre fotografiets tilknytning til døden, til det-der-har-været, som Roland Barthes skriver om i Det lyse kammer. Marianne Hirsch skriver om disse fotografier i artiklen "I Took Pictures", hvor hun kæder dem sammen med sin egen og mange andres tilbøjelighed til selv at tage billeder af Ground Zero og omgivelserne i mange dage efter 11. september. Hun nævner, at det også var almindeligt, at brandmændene fotograferede på privat basis under deres oprydningsarbejde. Var der tale om en pervers form for voyeurisme eller mangel på respekt for de afdøde? spørger hun og konkluderer, at der snarere var tale om på én gang 'at bære vidne' og at fotografere for at forstå og i sidste ende som sorgarbejde.

"Støvede sko i et smadret butiksvindue" nævner en af mine adspurgte studerende blandt sine tre udvalgte fotografier. En variation af de private efterlysningsfotografier, der metonymisk kom til at stå for alle de døde og derfor muliggjorde et kollektivt sorgarbejde, er fotografierne af tøj eller sko, dækket af støv. Som regel var det fotografier fra butikker, hvor vinduerne var blæst i stykker, og støvet havde lagt sig i et tykt lag over stabler af tøj eller sko. Disse fotografier - tror jeg - minder umiddelbart om de stabler af fx ure, smykker eller sko, som man har set i forbindelse med kz-lejrene under 2. Verdenskrig, hvor hvert af disse stykker tøj eller tilbehør som en 'pars pro toto' repræsenterer et afdødt menneske. De kan også minde om de lavastivnede kroppe eller indeksikale kropsaftryk i Pompeji. De støvdækkede butiksvinduer repræsenterede i sagens natur ikke virkelige afdøde eller indeksikale aftryk af afdøde kroppe, men jeg vil alligevel hævde, at både Pompeji og kz-lejr-fotos ligger som en inter-ikonisk reference under dem og er en medvirkende grund til, at dette motiv blev vist genkommende - som en matrice til at fatte det ufatbare; at flere tusind mennesker lå begravet i ruinerne fra World Trade Center.

En tredje variation af fotografiets rolle som sorgarbejde var udstillingen "Here is New York". Den blev stablet på benene i ugerne efter 11. september af en gruppe frivillige, bl.a. den anerkendte dokumentarfotograf Gilles Peress. Alle, amatører som professionelle, blev opfordret til at indsende deres fotografier, mere end tusind gjorde det, og alle blev repræsenteret med mindst ét fotografi, uden navn eller anden form for undertekst. De mere end tusind fotografier blev vist i et stort butiksvindue på Prince Street i SoHo fra d. 28. september og over hele efteråret, hvorefter de dels blev udgivet som bog med undertitlen "A Democracy of Photographs," dels turnerede verden rundt. Selv så jeg dem på Martin Gropius Bau i Berlin. Her var også smukke, velkomponerede fotografier med ikonisk potentiale i stil med den sorte røg, ruinerne, præsten og de tre brandmænd, men de mere uprofessionelle, spontane og decideret amatøristiske fotografier var i overtal - og kom for mange til 
at repræsentere en særlig grad af autenticitet $i$ al deres uperfekte spontanitet.

Ikoniske, ubevidst formatterede fotografier, der trækker på matricer fra film eller billedkunst, på allerede eksisterende fotografier som Iwo Jima-fotografiet eller mere ubevidste referencer til 'det apokalyptiske'; rystede amatøroptagelser af folk, der flygter desperat med en sort røgsky som baggrund; private turistfotografier taget i dage, uger og måneder efter 11. september - er de et generelt udtryk for, at der ingen sandhed findes, og at historien er en fiktion, som vi hver især skriver?

\section{Sontags opgør med sig selv og Baudrillard}

Den tyske avantgardekomponist Karlheinz Stockhausen kom som bekendt for skade at kalde 9/11 noget i retning af det største kunstværk til alle tider, hvilket vakte stor debat og harme. Men han havde vel til en vis grad ret i forhold til at betragte 9/11 som noget sublimt, noget ufatbart, noget vi ikke kan sætte ord på, men som rammer os. Mange af de europæiske aviser fokuserede som sagt i kraft af anvendelsen af storslåede og ja faktisk smukke røg- og ruinfotografier på begivenheden som en form for ufattelig, traumatisk hændelse.

Bogen Regarding the Pain of Others (2003) af Susan Sontag er på én gang et forsvar for kunstens og det skønnes ret i skildringen af uhyrligheder, krige og menneskelig død og et generelt forsvar for fotografiets skildring af virkeligheden. Bogen er skrevet i polemik mod både dem, der hævder, at en sådan ikke findes, at virkeligheden altid vil være medialiseret, og at noget først eksisterer, når det er blevet fotograferet, og dem, der på den anden side hævder, at fotografiet korrumperer den ægte erfaring og de ægte følelser. Bogen handler ikke specielt om 9/11, men snarere generelt om "atrocity images" gennem hele historien, altså fotografier af død, lemlæstelse, krig og grusomhed. I det hele taget kan man læse bogen som en nuanceret fortolkning af det fotografiske medie som på én gang en særlig bærer eller formidler af virkeligheden og en subjektiv fortolkning af samme.

Bogen er et forsvar for fotografiet som middel til "at betragte andres lidelser", som dens titel lyder på dansk. Og her kan patos og skønhed være et anvendeligt greb, som Sontag indsætter i en lang vestlig, kristen tradition for skildringer af menneskelige lidelser. "Der er skønhed i ruiner," skriver hun, og forsætter: "At anerkende skønheden i fotografierne af ruinerne fra World Trade Center i månederne efter angrebet blev betragtet som frivolt, som helligbrøde" (Sontag 2003: 76). Folk dristede sig måske til at bruge ordet "surrelle", men mange af fotografierne var smukke, mener Sontag. Hun angriber, hvad hun kalder "den nye kampagne mod det skønnes inautenticitet" og kritiserer "what a spectacle"-holdningen til fotografiet i dag. Med henvisning til bl.a. den berømte statue af Laokoongruppen, som befinder sig i Vatikanet, historiske skildringer af Kristi lidelse og til Goyas skildringer af den fransk-spanske krig i Spanien i begyndelsen af 1800-tallet, anfører Sontag, at det spektakulære altid har været et greb i den vestlige (kunst)historie til at forstå lidelse og ufattelig gru. "At mærke pulsen fra den kristne ikonografi i visse krigseller grusomhedsfotos er ikke en sentimental projektion" (Sontag 2003: 80), siger hun i et forsvar for patos som kommunikationsform og som en opfordring til også at anerkende det ufatbares tilstedeværelse i livet. Bogen er dels et opgør med hen- 
des egen tidligere læsning af fotografiet i bogen On Photography, dels med 'franske filosoffer' fra Guy Debord over Jean Baudrillard til André Glücksmann.

On Photography, der udkom i 1977, er en dybt pessimistisk, næsten ikonoklastisk bog. Den er skrevet med afsæt i Sontags egen oplevelse som teenager af George Rodgers' fotografier af massegrave i kz-lejren Bergen-Belsen, som gav hende et chok, hun i bogen hævder aldrig at have overvundet. I forhold til On Photography nævner hun i Regarding the Pain of Others to typiske holdninger til fotografiet, som paradoksalt nok hænger sammen i al deres modsathed: 1 . at ting først bliver virkelige, når de bliver fotograferet, 2. men at billederne efter flere gentagelser bliver mindre virkelige, gør os billedmætte, blinde, døve og ude af stand til at føle eller handle. Den sidste holdning kæder hun sammen med en generel kritik af modernitetens "følelseskorruption", som hun sporer fra Wordsworths forord til Lyrical Ballads fra 1800, over Baudelaires tekster i 1860'erne til sin egen første fotobog, hvor hun altså hævdede, at modernitetens billedstrøm har bedøvet menneskets sanseapparat. Sontag insisterer i Regarding the Pain of Others på, at der stadig findes en virkelighed, og hun kæder den pessimistiske modernitetsanalyse sammen med Guy Debords analyse af det moderne "société du spectacle", hans arvtager Baudrillards simulacrebegreb og samtidsteoretikere som André Glücksmann bl.a., der efter en tur som endagsturist til Sarajevo under den eks-jugoslaviske borgerkrig hævdede, at krigen udelukkende blev afgjort i medierne. Hun kalder beskrivelsen af det medialiserede, simulakrale spektakelsamfund - hvad enten den er konstaterende eller kulturpessimistisk - for konservativ og provinsiel (Sontag 2003: 110). Provinsiel i den forstand, at man tager sit eget, vestlige, begrænsede udgangspunkt, sin egen lille befolknings mediekultur som afsæt for en generel analyse, hvor alle beskrives som 'tilskuere', og herved kommer til at anføre, at der ikke findes virkelig lidelse i verden.

I Baudrillards kommentar til 9/11, "denne katastrofefilm fra Manhattan", "terrorismen som skuespil", "vores eget grusomhedens teater", "det spektakulære i sin reneste form" (Baudrillard 2001/2002: 165), skrevet som en artikel i Le Monde 3. november 2001, beskriver han i forlængelse af sine tidligere simulacreanalyser 9/11 som en "billedbegivenhed", forklarer at 9/11 blev "billedets gidsel", og at billederne samtidig neutraliserede begivenheden (Baudrillard 2001/2002: 163-164). Folk troede måske, at det, de så på billederne, for en gangs skyld var virkeligheden:

4f Men kan virkeligheden egentlig overgå fiktionen? Hvis den ser ud til at gøre det, er det fordi den har optaget fiktionens kraft i sig, og selv er blevet fiktion. Man kunne næsten sige at virkeligheden er jaloux på fiktionen, at det reelle er jaloux på billedet. [...] Sammenstyrtningen af de to tårne i World Trade Center var utænkelig, men det at det var utænkeligt er ikke nok til at gøre det til en virkelig hændelse. Ekstrem vold er ikke tilstrækkelig til at gøre noget virkeligt. For virkeligheden er et princip, og det er princippet, der er gået tabt. Virkelighed og fiktion er uløseligt knyttet sammen, og fascinationen af attentatet er først og fremmest en fascination af billedet... (ibid. 164)

Han slutter sin analyse med at kalde 9/11 "en ikke-begivenhed, en begivenhed som egentlig ikke har fundet sted. Dette er dens eksistensberettigelse: at erstatte en vir- 
kelig, en enorm begivenhed, enestående og uforudset, med en repeterende pseudobegivenhed, et déjà-vu" (ibid. 167).

\section{Billedøkologi, Bilderverbot?}

I sin første, pessimistisk-ikonoklastiske bog plæderede Susan Sontag for en "billedøkologi"; en sparsom og indskrænket anvendelse af fotografier over for gru, krig, død og lidelse. Nu skriver hun: "Lad de grusomme billeder hjemsøge os" (Sontag 2003: 115). "Det er blevet en kliché i den urbane vestlige diskussion af grusomhedsfotografier at antage, at de stort set ingen effekt har, og at der er noget grundlæggende kynisk i at sprede dem" (Sontag 2003: 111).

Det at møde verden, inklusiv dens mere grusomme og ufatbare sider, gennem fotografier er et moderne livsvilkår, der ikke nødvendigvis svækker endsige eliminerer det levede liv eller de grufulde handlinger, hævder Sontag. Hun nævner, at man i nutidens billedsamfund også altid må være kritisk opmærksom på det, der ikke vises i billeder. Men når det er sagt, insisterer hun på, at det at huske via fotografier er en etisk handling, og at $i$ al fald nogle fotografier $i$ dag kan fungere som "sekulære ikoner" med en funktion og et følelsesudtryk, som er rundet af eksempelvis en religiøs billedtradition.

Polemikken om billedøkologi eller ligefrem 'Bilderverbot' vs. retten til at repræsentere genkender man fra den Holocaustrepræsentationsdiskussion, der især har floreret i kølvandet på nyere mindesmærkediskussioner samt film som den amerikanske tv-serie Holocaust fra slutningen af 1970'erne, Claude Lanzmanns Shoah og Steven Spielbergs Schindler's List.

Den amerikanske tegner Art Spiegelmans tegneserie Maus, der handler om Holocaust (hans 9/11-bog omtales andetsteds i dette nummer), kan læses som et nuanceret indlæg i denne debat. Bogen handler bl.a. om hovedpersonen Arts kvaler ved overhovedet at tegne det forfærdelige, genfortalt via samtaler med Arts far, der er Holocaustoverlever. I en scene sidder Art, der er født efter krigen, hos sin psykiater Pavel og taler om sin skyld og generelle utilpashed ved slet ikke at have taget del i "Auschwitz" og ved alligevel at forsøge at skildre det. "Det er måske bedre ikke at få flere historier. De døde kan alligevel ikke fortælle deres", siger Pavel. Art svarer: "Hm. Samuel Beckett sagde engang: 'Hvert ord er som en unødvendig plet på stilheden og intetheden"', og efter et ordløst tegnet pausefelt fortsætter Art: "På den anden side så sagde han det" (Spiegelman 1992: 45).

Fotografiet et det mest repræsenterende, det mest referentielle medie, men også det medie, der villigst lader sig udlåne til allehånde fritsvævende betydninger og kontekster. Er modsvaret til spektakelsamfundets medialisering en billedøkologi eller et billedforbud? Den nyere, teoretiske Holocaustrepræsentationsdiskussion kan låne os en del frugtbare modbegreber i forhold til dette skisma. Litterater og historikere som Geoffrey Hartman, Dominick LaCapra og Saul Friedlander har talt imod repræsentationsforbuddet, imod 'closure', og for en åbnende, flerfacetteret, strittende, modsætningsfyldt og metarefleksiv brug af ord og billeder (Hartman 1994, Hartman 1996, LaCapra 1994, Friedlander 1992). 
Tiden efter 2. Verdenskrig er i en tysk sammenhæng blevet beskrevet som en "Stunde Null" (sammenligningen med betegnelsen Ground Zero er nærliggende), og det tog flere tiår, før verden for alvor begyndte at diskutere, hvordan man skulle vise og forholde sig til Holocaust. Hele denne repræsentationsdiskussion fik for alvor vind i sejlene i 1980'erne og 1990'erne, og den bliver ved med at revitaliseres, efterhånden som nye billeder og nye fortællinger dukker frem, senest i forbindelse med United States Holocaust Memorial Museums offentliggørelse af et privat nazifotoalbum. I forhold til Holocaust så vi 9/11 billedliggjort, mens det skete, og billedmængden var enorm. Som vi har set det, var mange motiver de samme, mange fotografier var konstrueret ud fra et snævert udvalg af visuelle matricer hentet i den umiddelbart nære visuelle kultur såvel som et bredere udvalg af kulturhistoriske 'patosformler', og fotografierne fik forskellige konnotationer bestemt af bl.a. specifikke nationale kontekster.

I Susan Buck-Morss' bog Thinking Past Terror diskuterer hun bl.a. og i lyset af 9/11, hvordan billeder kan skabe kollektiv bevidsthed. Den kritiske teori og den hegelianske tradition, som hun selv er rundet af, var sandhedssøgende, og her handlede det om billedkritisk at komme bag om billedernes skin. Men "det visuelle er det, vi har", siger Buck-Morss. Billederne er vores fælles erfaring, og vi kan ikke komme uden om dem. I bogen forsøger hun derimod at formulere en mere positiv billedopfattelse; at de kan bruges som politiske tankeredskaber for nye erkendelser gennem det visuelle.

Konklusionen på udbredelsen af de former for 9/11-fotografi, som jeg har kategoriseret her, er langt fra entydig. Man kan - som Baudrillard - vælge at diagnosticere virkelighedens endelige sammenbrud, eller man kan - som Sontag, BuckMorss og overtegnede eller med Qvortrups begreb om "en struktureret dissensus" - vælge en, måske mere eksistentiel, tro på fotografiets flerfacetterede tilgang til det virkelige og en tiltro til aflæserens evne til at se og indse ved hjælp af fotografierne.

Marianne Hirsch skrev oprindeligt sin artikel om amatørfotografierne fra 9/11 og deres funktion i sorgarbejdet om vinteren 2001/2002. Da hun skulle udgive den i tidsskriftet The Scholar \& Feminist i 2003 tilføjede hun et efterord, hvor hun beklagede, at sorgen - og dermed også de sørgefotografier, hun havde skrevet om - var blevet et alibi for USA's invasion af Irak og et effektivt redskab i det amerikanske propagandaapparat (Hirsch 2003: 8).

Lad mig gentage et af de citater af Lars Qvortrup, som jeg anvendte i begyndelsen af denne artikel: "Offentlighedens funktion er ikke at frembringe en fælles, diskursiv sandhed, men at frembringe et tematiseret rum af stridende fortolkninger, der i deres dynamiske kompleksitet kan matche den omverdens-kompleksitet, som attentatet mod World Trade Center fremkaldte." En naiv utopi? Tja, udfordringen i dag er i mine øjne ikke en kulturkritisk billedforbandelse, men vel snarere på én gang at lade fotografierne fungere som matricer til at agere i og forstå den verden, vi lever i, samtidig med at man forsøger at forholde sig kritisk til deres kontekst, anvendelse, symboltilskrivelse; til det, de ikke viser, og til det faktum, at fotografierne ikke er vores eneste tilgang til verden. 


\section{Noter}

I I Jacques Le Goff og Pierre Nora: Faire de l'histoire I. Nouveaux problèmes 1974 s. 288. Citeret fra Chéroux 2007. Chéroux nævner en lignende brug af begrebet matrice hos Paul Rock : "News as eternal recurrence", i Stanley Cohen og Jock Young (red.): The Manufacture of News, 1981.

2 Qvortrups anbefalelsesværdige antologi Mediernes 11. september rummer bidrag fra en lang række især danske billedforskere, som også skriver om de fleste af de fotografier, jeg nævner i indeværende artikel ud fra en lignende ‘åben' optik i forhold til begrebet “mediematricer”, der bruges som samleoverskrift for bidrag af Kirsten Drotner, Gitte Braut Rose, Rikke Schubart og Jesper Zimmer Hansen. Jeg hævder således bestemt ikke at bidrage med afgørende nyt i forhold til antologien, men måske bare i al beskedenhed at supplere med nogle flere billeder, analysevinkler og teoretiske optikker.

3 Mundtligt foredrag ved en international fotoforskerkonference i Bergen, nov. 2007.

\section{Litteratur}

Baudrillard, Jean : “Terrorismens ånd”. Oversættelse fra Le Monde 3. nov. 2001, i Claus Clausen og Rasmus Øhlenshlæger Madsen (red.): Tirsdag 11. september 2001. Eftertanker, Kbh.: Tiderne Skifter, 2002.

Buck-Morss, Susan: Thinking Past Terror. Islamism and Critical Theory on the Left, London: Verso, 2003.

Chéroux, Clément: "Le déjà-vu du 11-Septembre. Essai d'intericonicité”. Études photographiques, no. 20, juin 2007. Paris: Société Francaise de Photographie.

Drotner, Kirsten: "Når virkeligheden overgår fiktionen: mediematricer mellem det kendte og det ukendte", i Qvortrup (red.), 2002.

Eisenman, Stephen: The Abu Ghraib Effect, London: Reaktion Books, 2007.

Friedlander, Saul (red.): Probing the Limits of Representation. Nazism and the "Final Solution", Cambridge, Mass.: Harvard University Press, 1992.

Hartman, Geoffrey H. (red.): Holocaust Remembrance, Cambridge Mass.: Blackwell, 1994.

Hartman, Geoffrey H.: The Longest Shadow. In the Aftermath of the Holocaust, Bloomington: Indiana Univ. Press, 1996.

Hirsch, Marianne: "I Took Pictures. September 2001 and Beyond". The Scholar \& Feminist Online, vol. 2, no. 1, Summer 2003, Bernard Center for Research on Women, http://www.barnard.edu/ sfonline/ps/hirsch2.htm. Også trykt i: Judith Greenberg (red.): Trauma at Home, Lincoln: University of Nebraska Press, 2003.

LaCapra, Dominick: Representing the Holocaust. History, Theory, Trauma, Ithaca: Cornell Univ. Press, 1994.

Sontag, Susan: Regarding the Pain of Others, New York: Picador, 2003.

Spiegelman, Art: Maus, Kbh.: Politisk Revy 1987 (bind 1) og 1992 (bind 2).

Qvortrup, Lars (red.): Mediernes 11. september, Kbh.: Gad, 2002. Forfatter til indledning samt artiklen "Mediernes og offentlighedens 11. september". 